\author{
Mentor's Introduction \\ Hope Irvine, Syracuse University
}

In our field art teachers spend most of their time nurturing their students, working to help them develop their own ideas and present them visually to others. This makes it difficult for teachers, accustomed to making only positive comments, to make critical statements that will still nurture their student teachers. Tanya found that for ordinary things such as appearance or lateness they commented without hesitation. They offered resources and references without hesitation. But for more difficult subjects such as developing classroom management, building on strategies for improving presentation or demonstration skills or re-directing lesson plans they seemed to avoid direct negative statements and tried to change the behavior by giving other examples.

As one immediate result of her work she developed a seminar for our host teachers on script-taping. It featured one of her dissertation subjects presenting the method she used with her student teacher to point out actualities in the classroom in a non-judgmental way that could then be discussed together. The art teachers responded enthusiastically and are eager for more seminars.

Tanya's dissertation suggests directions for further research such as investigating the relationship between knowing about feedback techniques and teachers' field application of those techniques to create relevant feedback systems grounded in both theory and practice. Exploring specific challenges art teachers face when providing feedback in relation to their distinct circumstances that may in-turn inform workshop content for professional development. Exploring relationships between university supervisors and host teachers to consider equitable systems for supportive professional development opportunities between host teacher and university supervisor pairs. And finally to further study host teachers' supervisory practices to form a deeper understanding of feedback and conditions for learning provided by host teachers during student teaching practica.

Her work shines light on the obligation a university has for enabling host teachers to supervise our students. She closes her dissertation with a proposition inspired by one of its participants' notions that 'people really do the best they can with what they have'. And proposes that; if people do indeed 'do the best they can with what they have,' why not give them the best with which to do it.

Tanya Silverstein, Syracuse University

\title{
Host Art Teachers and Their Feedback During Student Teaching Practicum
}

\author{
ABSTRACT \\ Host teachers' feedback to student teachers is an important component in the professional development of \\ teachers. Yet, other than anecdotal accounts, little is known about host teachers' feedback experiences. This \\ qualitative study examined the nature of practice, attitudes and experiences of five Syracuse University art \\ education host teachers with regard to providing feedback to student teachers. Findings show that \\ participants viewed the purpose of feedback as providing support for student teachers' success. Although \\ host teachers shared common perspectives about the function of feedback, the complex nature of their \\ practice was unique and dynamic. Also noted was the lack of support for time for feedback conferences and
}


professional development centered on supervisory training. These findings raise questions about the ways host art teachers relate their beliefs, perceptions and experiences in providing feedback to student teachers and how teacher educators can better assist them with balancing technical practice with feedback demands. In conclusion, it is emphasized that support systems be developed to meet the needs of host teachers that supervise art education student teachers.

\section{INTRODUCTION}

Teaching art is a complex and demanding profession. Art teachers need to be familiar with materials available for making and responding to art and skilled in writing lesson plans with objectives and assessments for student learning. Art teachers are expected to be knowledgeable of resources for extending art experiences into interdisciplinary, multicultural, and visual cultural areas. Additionally, art teachers must recognize diverse capabilities, interests, and needs of students in the art class. Working within a schedule that often necessitates shifting several times a day from working with students in elementary, middle, and high school, art teachers determine what to teach, how to teach it, whether students have learned it, and what to do next (Stone, 2001). Thus the art teachers' role takes on greater dimensions when

they agree to accept student teachers into their practices. According to Thies-Sprinthall (1984) "One of the most troubling problems in pre-service student teaching development has been the quality of field supervision" (p. 53). This study begins with acknowledging the problem of preparing host teachers for roles in field service supervision.

\section{Host Teacher Feedback and Learning to Teach}

Engaging in a student teaching practicum is a complicated emotional and interpersonal experience that significantly impacts teacher development (Koerner, Rust \& Baumgartner, 2002). Most teachers maintain that the most important elements in their professional education were the school experiences generated during student teaching (Guyton \& McIntyre, 1990). Many researchers suggest that host teachers are the most influential people in pre-service teachers' training experience since they have daily contact with student teachers and play fundamental roles as mentor, role model and friend (Bunting, 1988; Glickman \& Bey, 1990; Goodlad, 1990; Hargreaves \& Fullan, 2000; Kahan, Sinclair, Saucier \& NguyenCaiozzi, 2003). 
An important component in preparing student teachers during student teaching practicum is providing feedback on their teaching (Shantz \& Ward, 2000). Many researchers describe effective feedback as frequent, specific, continuous, relevant to the student teacher's needs, and provided by a [host] teacher educated in delivering feedback (Acheson and Gall, 1992; Barnes and Edwards, 1984; Blank and Heatherton, 1987; Morehead, Lyman and Waters, 1988; Woolever, 1985). However, current research on pre-service teaching experience has often neglected the point of view of the [host] teacher (Kahn, 2001). Moreover, there is a lack of data available on [host] teachers' view of the student teaching experience as expressed by the [host] teachers themselves (Koerner, 1992; Tjeerdsma, 1998). Specific to art education, Zimmerman (1994) acknowledges the lack of research with respect to the impact of influences outside the university setting on student teachers. Kahn (2001) posits that more studies are needed to give [host] teachers the opportunity to share their opinions, beliefs, and actual practices. Therefore, to better understand teacher education programs careful studies of student teaching practica are needed as it is considered the single most influential field experience in a teacher education program (Bunting, 1988; Goodlad, 1990; Hargreaves \& Fullan, 2000).

Many state and national organizations including the Association of Teacher Educators (ATE, 2000), and National Council for Accreditation of Teacher Education (NCATE, 2003), recognize the importance of [host] teachers and include recommendations for supervision as part of their program standards. NCATE's suggestions include establishing supportive and collaborative systems between [host] teachers and the university in order to jointly determine specific placements of student teachers, and to select and prepare clinical faculty for their roles as mentors and supervisors. While many of these reports include contributions from [host] teachers, very little information from [host] teachers about their work with student teachers exists.

\section{Purpose of the Study}

The purpose of this study was to explore the nature of art education host teachers' feedback practices from their perspectives. Participants for this study were approached as art teachers with expertise in hosting student teachers that could reveal details about providing feedback to student teachers.

Participants were purposefully selected with attention to diversity from the Syracuse University Art Education Host Teacher Registry. 
Three initial questions guided the development of qualitative interviews to examine host teachers' feedback to student teachers:

1. What are art education host teachers' perspectives on, and experiences with, providing feedback to student teachers? What informs their beliefs and practices?

2. How, if at all, do art education host teachers provide feedback to their student teachers? What informs their decisions?

3. To what extent does the nature of feedback practices change when addressing diverse student teacher situations? What influences these decisions?

\begin{tabular}{|l|l|l|l|}
\hline Participant & Level \& Setting & $\begin{array}{l}\text { Number of Years } \\
\text { Teaching }\end{array}$ & $\begin{array}{l}\text { Number of Student } \\
\text { Teachers Supervised }\end{array}$ \\
\hline Joan & Urban High & 10 & 10 \\
\hline Laura & Urban Middle & 7 & 4 \\
\hline Nancy & Suburban High & 26 & 15 \\
\hline Sandy & Rural Elementary & 30 & 4 \\
\hline Trina & Suburban Middle & 34 & 23 \\
\hline
\end{tabular}

Figure 1. Demographics of Host Art Teachers Selected from Syracuse University Host Teacher Registry

Through analyzing participants' perspectives, practices and beliefs in regard to providing feedback to student teachers it became evident that they were informed and influenced by: (a) experiences in teaching, (b) personal experiences, and (c) professional development.

\section{DISCUSSION}

This study provided insight into how some host art teachers developed feedback practices and offered some understanding about what informed their routines. However, the intent of this study was not to generate a broad view of host teachers' practices with student teachers. Rather, its purpose was to work toward a better understanding of the nature of particular art education host teachers' feedback practices by looking closely at an exclusive collection of teachers' experiences. For that reason, findings should be interpreted as experiences exclusive to participants in this study and may prove to be most significant to art education host teachers with conditions similar to those studied.

Although participants defined the purpose of feedback as providing support for success, sharing ideas and communicating suggestions to improve teaching, the nature of their practices varied. Some host teachers perceived their feedback practices through a lens of mother. Others identified with descriptions of 
director, mediator, mentor or coach. Moreover, host teachers' implementation of practice varied in relation to particular experiences and circumstances. Thus, although host teachers shared a common perspective for the function of feedback the nature of their practice proved unique and dynamic.

Making Sense of Feedback Through Teaching Experiences and Personal Encounters.

Sergiovanni \& Starratt, (1993) cite that when supervisors and teachers define their work they do not tend to characterize their practices as being informed by theory. Instead, they describe how they depend on what works, hunches about what works, the principles that they draw from their hunches and ideas that are developed from a practical view of their work. Thus, since much of the theory that directs professional practice is implicit and informal, teachers may claim they are not being theoretical. Yet, it is difficult to teach or supervise without being theoretical. Hence, when professionals claim they do not apply theory to practice, it is likely that what they mean is they are not aware of theoretical underpinnings that ground their work (Sergiovanni \& Starratt, 1993). Likewise, this study found that participants did not describe theoretical perspectives in philosophical terms. Instead, most host teachers described their practices and beliefs within the realm of intuition and perspectives of how they defined their feedback roles. Since participants in this study relied heavily on their experiences as student and host teachers to inform their conceptual beliefs, perspectives and practice, their feedback beliefs and practices were constructed through personal and professional experiences. Although these host teachers included feedback characteristics descriptive of Practical Initiation and Critical Interventionist Models (Maynard, 1996), they did not specifically refer to these models as theoretical foundations. Instead they described what they did or how they did it. Therefore, it became apparent that the teachers were unaware or did not have a name for influences on their practice or beliefs beyond their own design. One explanation for the lack of theoretical markers is Dussault's (1970) suggestion that the field of education lacks shared scholarly language about theory or theory building. Furthermore, Duquette (1994), Watts (1987) and Zeichner (1987) reason that factors such as poorly defined roles, purpose and goals in addition to insufficient preparation for teachers' task of supervision are cause for such limitations.

More specific to teaching art, the lack of theoretical foundation in art education exists to some extent because the development of theory depends upon professionals to work together toward like theoretical goals. While many researchers in the field of art education have developed research on 
corresponding topics, few in the past have pursued it with the purposed intention of establishing theory (Freedman, 2004). When host teachers were probed for clarification during interviews in regard to what influenced their practice or beliefs many hesitated to respond. When teachers did respond they often began with, “I don't know" or "You're really making me think", or "That's a hard question". Hence, it was my impression that host teachers began to develop theoretical perspectives for their work through the process of interviewing about feedback.

Construction of Feedback, Professional Development and Roles Teachers Play. In view of the critical importance of feedback during student teaching experiences, host teachers play an essential and influential role in the development of student teachers (Landis, 1993). Yet, Ramanathan and Wilkins-Canter (2000) posit that most [host] teachers do not receive training for their role as evaluators. Likewise, this study found that none of the participants had received education specific to their roles as host teachers.

However, evidence exists that teachers formally prepared for their roles as host teachers are more effective. In Zeichner and Liston (1985) findings revealed that when [host] teachers were educated in inquiry oriented/reflective supervision, pre-service teachers were less apt to follow conservative practices. Although teachers in this study had not received training particular to supervising student teachers there were two teachers who had participated in district supported, professional development series focused on observation and mentoring. By adapting knowledge acquired from workshop series' these teachers approached observing student teachers and providing explicit feedback to them with deeper cognition and reflective specificity than host teachers without training. This pair of teachers demonstrated their understanding of feedback by narrating detailed descriptions of specific strategies and rationales for practice grounded in models of clinical supervision. Furthermore, this pair of host teachers identified professional development workshops offered by their respective school districts as the primary influence on their theoretical and practical approach to providing feedback to student teachers.

Professional Development and Construction of Feedback. Previous research indicates that student teacher supervision has not received the recognition it deserves (Bain, 2002). Furthermore, Bain states that little training or support services exist for host teachers. This study indicates that Bain's observation of the lack of training opportunities for host teachers continues. Although two teachers participated in workshops for 
mentoring or observation the programs were not developed with supervising student teachers in mind. However, the teachers recognized possibilities for application of observation strategies for feedback practices for use with student teachers. Consequently, the teachers adapted practices encountered in the professional development workshops to fit their needs as host teachers.

\section{Implications}

Although this was a small scale, descriptive study, findings suggested possible implications for the field of art education. Findings indicated that the nature of supervising art education teachers' feedback practices, beliefs and perceptions were dependant on personal and professional experiences. Additionally, findings suggested that teachers' feedback practices were strongly linked to their ability to synthesize their experiences and adapt or construct feedback systems to circumstances unique to their teaching setting and student teachers' needs. However, within teachers' accounts of feedback perspectives and practice there seemed to be a gap between most feedback practices and theoretical perspectives. Findings from this study suggest a need for (a) blending theoretical and intuitive perspectives of feedback (b) the need for knowledge of clinical observation and related feedback practices and (c) a need for professional interaction between art education host teachers.

This study suggests that it may be important to narrow the gap between practice, academic knowledge and intuitive understanding of supervising art education teachers' work. First, as Cohen-Evron (2002) states, most art teachers work in isolation. Many art teachers express frustration connected with working alone and welcome sharing ideas with others. Specific to this study art education host teachers have developed feedback practices worth sharing with others. It may be beneficial to art education communities to organize opportunities to share feedback practice strategies with each other. Second, some art education host teachers have made connections between clinical observation methods gained from professional development and their work with student teachers. Thus, host teachers may benefit from professional development series focused on clinical observation methods with focus on adaptations of methods and practices specific to their needs. My study indicated that many host teachers began to develop theoretical standpoints while in the process of being interviewed. As Freedman (2004) suggests there is a need for creating opportunities for critical dialogue in order to establish theoretical perspectives through collaborative relationship within the art education professional community. Moreover, as Atkinson and 
Claxton (2000) point out, success in professional practice depends on interconnected "intuitive thinking that underlies action and rapid decision making, the analytical and objective thinking that allows teachers to plan for learning and the reflective thinking that is crucial to monitoring and learning from experience" (p.

6). Thus, when connections between theory, intuition and practice are made through reflecting on their feedback practices host teachers may develop a more specific understanding of their role. Furthermore, they may begin to identify explicit rather than implicit notions of feedback. Finally, host art education teachers should be presented with the opportunity to work together beside university scholars. Through collaborative work host teachers may begin to link their intuitive feedback constructs and practices with scholarly developed theories and practices for providing supervisory feedback. Thus, it may be possible to begin establishing a shared theoretical foundation that would narrow the gap between practice, academic knowledge and intuitive understanding for providing productive critical feedback to student teachers.

\section{Recommendations}

Findings of this study may benefit interest holders in the field of art education teacher preparation. Recommendations grounded in this study's findings provide suggestions for art teacher preparation programs.

\section{Recommendations for Art Education Host Teachers.}

Host art teachers may benefit from organizing and participating in forums that focus on an agenda of sharing and developing feedback practices informed by personal experience. Findings revealed that when teachers participated in workshops created by teachers for teachers they were inclined to participate, consider new ideas and apply and adapt innovative techniques to their feedback practice and teaching conditions. Findings also support a recommendation for the development of critical and reflective thinking

practices. When host teachers were able to synthesize experiences both reflectively and critically they were best able to guide student teachers in similar thinking. Therefore, host teachers may benefit from further development of these skills. Thus, teachers should have opportunities to attend workshops and conferences to develop critical reflection practices. Finally, to keep current in the field, host art education teachers need to take an active role in recommending professional subscriptions to their librarians on the topic of supervision for their professional shelves. 
Recommendations for School Administration. Findings from this study indicate that art teachers working with student teachers are not provided with supplemental time in their pre-determined schedules to conference with student teachers. Instead, they must incorporate feedback delivery into existing prepperiods that are designated for preparation of class materials, lunch periods, and other special duties. As well, instructional time, and time before and after school becomes fair-game for providing feedback to student teachers. Hence, host teachers often find themselves inventing strategies to provide feedback within a time frame that is inadequate for significant feedback. Working on borrowed time is not an optimum arrangement for working with student teachers. Working toward relieving the ever-present time-bind art teachers operate within may influence their feedback practices. Suggestions for school administrators include creating sufficient time within the structure of host art teachers' schedules to permit them to engage in meaningful pre and post conferences with student teachers.

The issue of teaching and supervising in isolation is another area that may be addressed by school administrators. Often art teachers find themselves as the only art education host teacher in their buildings. However, there may be art teachers working with student teachers in placements throughout and across districts. This group of host teachers may benefit from meeting with each other. Because of the structure of some districts' scheduling differences and distance between buildings, it is recommended that Superintendent's Day workshop activities are developed to support supervising art teachers' needs. Additionally, university and school communities may benefit from developing strategies to incorporate electronic technologies with face-to-face workshops to connect with each other.

Host teachers need to be able to strike a balance between personal perspectives, experiences, intuitive practices and theoretical standpoints. Art education teacher preparation practices should provide support to achieve this challenge in a variety of ways. Workshop series with a focus on clinical supervision practices should be offered during times that host teachers are able to attend. Furthermore, so that teachers' personal approaches to feedback are not discounted, panels of host teachers to discuss self-developed practices for a variety of situations and settings should be incorporated as part of clinical workshop agendas. Finally, a menu of 'art teachers' tools' for collecting and analyzing teaching data, and providing meaningful feedback should be developed during feedback workshops. This document should be included in department handbooks. 
Findings from this study indicated that despite the importance placed on student teaching practica, considering their own experiences generally develops host teachers' feedback practices. To develop feedback practices host teachers relied on knowledge gained as student teachers, in-service teachers and host teachers. While some teachers took advantage of professional development workshops organized by their school districts to construct perspectives and practices, most relied on intuition and personal and professional experiences to inform their approach to feedback. Moreover, some teachers did not feel that the university they served supported their roles. Departments of Art Education need to ensure that host teachers are prepared for the roles they are expected to fulfill. Without adequate professional development host teachers may not receive information necessary to carry out their responsibilities effectively. For host teachers to be successful in preparing teachers of tomorrow, funding must be provided, fair schedules determined and democratic agendas designed. Pairing student teachers with experienced art teachers that are able to get kids to do art is not enough. In order to prepare student teachers for the profession of teaching art it is important to assign them to host teachers that are able to provide meaningful feedback that is informed by personal and professional experience and grounded in theoretical principle.

In addition to establishing elusive theoretical and conceptual frameworks this knowledge may in turn provide teaching communities with opportunities to put Freedman's (2004) notion, that theoretical frameworks develop through practice and practice is shaped by theory, into action by organizing professional development for departments of education with informed guidelines to create sustained, meaningful workshops for host art teachers.

Therefore, I conclude this work with a proposition inspired by one of its participants' notions that 'people really do the best they can with what they have'. And propose that; if people do indeed 'do the best they can with what they have,' why not give them the best with which to do it.

\section{References}

Acheson, K. \& Gall, M. (1992). Techniques in the clinical supervision of teachers: preservice and inservice applications. NY: Longman Publishing Group.

Association of Teacher Educators. (2000). Standards for field experiences in teacher education. (Eds.), E. Guyton \& D. Byrd. Reston, VA: Author.

Atkinson, T. \& Claxton, G. (Eds.). (2000). The intuitive practitioner: on the value of not always knowing what one is doing. PA: Open University Press. 
Bain. C. (2002). Practical suggestions for supervising student teachers. In C. Davis (Ed)., NAEA Advisorys. Reston, VA: National Art Education Association.

Barnes, S., \& Edwards, S. (1984). Effective student teaching experience: A qualitative-quantitative study (Report No. 9060). Austin, TX: Universtiy of Texas at Austin. Research and Development Center for Teacher Education.

Blank, M. \& Heathington, B. (1987). The supervisory process: A consistent approach to help student teachers improve. The Teacher Educator, 22, 2-14

Bunting, C. (1998). Cooperating teachers and the changing views of teacher candidates. Journal of Teacher Education, 39(2), 42-46.

Cohen-Evron, N. (2002) Why do good art teachers find it hard to stay in the public school system? Studies in Art Education: A Journal of Issues and Research. 4 (1), 79-94.

Dussault, G. (1970). A theory of supervision in teacher education. New York: Teachers College Press.

Duquette, C. (1994). The role of the cooperating teacher in a school-based teacher education program: Benefits and concerns. Teaching and Teacher Education, 10, 345-54.

Freedman, K. (2004). Becoming a researcher in art education: constructing theory based on research. Studies in art education a journal of issues and research, 45 (4) 283-284.

Glickman, C. \& Bey, T. (1990). Supervision. In: W.R. Houston (Ed. ) Handbook on Teacher Education. NY: Macmillan.

Goodlad, J. (1990). Teachers for our nation's schools. San Francisco: Jossey Bass.

Guyton, E., \& McIntyre, D. (1990). Student teaching and school experiences. In W.R. Houston, M. Haberman, \& J. Sikula (Eds.), Handbook of research on teacher education (pp. 514-34). New York: Macmillan.

Hargreaves, A., \& Fullan, M. (2000). Mentoring in the new millennium. Theory into Practice, 39 (1), 5056.

Kahan, D., Sinclair, C., Saucier, L. \& Nguyen-Caiozzi, N. (2003). Feedback Profiles of Cooperating Teachers Supervising the Same Student Teacher, The Physical Educator. 60(4), 180-193.

Koerner, M., Rust, F., \& Baumgartner, F. (2002). Exploring roles in student teaching placements. Teacher Education Quarterly, 29 (2), 35-58.

Landis, C. (1993). Sharing the art apple: Cooperating art teacher and student teacher relationships - part I phase I: Preparation for the field experience. In A. L. Nyman (Ed.), Instructional methods for the artroom: NAEA Advisorys. Reston, VA: National Art Education Association.

Maynard, T. (1996). The limits of mentoring: The contribution of the higher education tutor to primary student teachers' school-based learning. In J. Furlong \& R. Smith (Eds.), The Role of Higher Education in Initial Teacher Training. (London, Kogan Page).

Morehead, M., Lyman, L. \& Waters, S. (1988). A model for improving student teaching supervision. Action in teacher education, 10, 39-42.

National Council for Accreditation of Teacher Education (2002). Professional standards for the accreditation of schools, colleges, and departments of education. Washington, D.C.: Author. 
Ramanathan, H., Wilkins-Canter, E. (2000). Preparation of cooperating teachers as evaluators in early field experiences. Action in teacher education, 22 (1), 101-11

Sergiovanni, T. \& Starratt, R. (1993). Supervision: a redefinition. NY. McGraw-Hill, Inc.

Shantz, D. \& Ward, T. (2000). Feedback, conversation and power in the field experience of preservice teachers. Journal of instructional psychology,27 (4), 288-94.

Stone, D. (2001). Using the art museum. Worcester, MA: Davis Publications, Inc.

Thies-Sprinthall, L. (1984). Promoting the developmental growth of host teachers: Theory, research, programs, and implications. Journal of teacher education, 35 (3), 53-60.

Watts, D. (1987). Student Teaching. In M. Haberman \& J.M. Backus (Eds.). Advances in teacher education 3, 151-167) Norwood, NJ: Ablex.

Woolever, R. (1985). State-mandated performance evaluation of beginning teachers: implications for teacher educators. Journal of teacher education, 36, 22-25.

Zeichner, K. (1987). The ecology of field experience: Toward an understanding of the role of field experiences in teacher development. In M. Haberman \& J.M. Backus (Eds.). Advances in teacher education. 3, 94-117. Norwood, NJ: Ablex.

Zeichner, K. \& Liston, D. (1987). Teaching student teachers to reflect. Harvard Educational Review, 57 (1), 23-48. 